\title{
Eutrophication Levels through San Pedro-Mezquital River Basin
}

\author{
María Elena Pérez López ${ }^{1 *}$, Maria Guadalupe Sanchez-Martinez ${ }^{1}$, \\ Maria Guadalupe Vicencio de la Rosa ${ }^{1}$, Margarita Teutli Leon ${ }^{2 *}$

\footnotetext{
${ }^{1}$ National Polytechnic Institute, Interdisciplinary Research Center for Integrated Regional Development (IPN-CIIDIR-DGO), Durango, México; ${ }^{2}$ Engineering Department, Autonomous University of Puebla (B.U.A.P), Puebla, México.

Email: *maelena0359@yahoo.com, ${ }^{*}$ teutli23@hotmail.com
}

Received September $22^{\text {nd }}, 2013$; revised October $21^{\text {st }}, 2013$; accepted November $18^{\text {th }}, 2013$

Copyright (C) 2013 María Elena Pérez López et al. This is an open access article distributed under the Creative Commons Attribution License, which permits unrestricted use, distribution, and reproduction in any medium, provided the original work is properly cited.

\begin{abstract}
This paper presents an eutrophication diagnosis for the San Pedro-Mezquital basin at Mexico; procedure accounted to set up 10 sampling points distributed along the river pathway, and sample collection was done at two extreme conditions: rainy season and dry season. Five parameters were analyzed in this work: $\mathrm{pH}, \%$ Dissolved Oxygen, reactive phosphorus, and nitrogen species as nitrate and ammonia compounds. Obtained concentrations were statistically analyzed to establish if there were significant differences among sites and between seasons; being the dry season the one with higher nutrient content, ammonia can be considered statistical significance due to the total values found for each season. Calculation of the Karydis eutrophication index for each parameter showed that more damaged sites were those nearby the cities, and most of the sampled sites belonged to the eutrophic category.
\end{abstract}

Keywords: Eutrophication; Pollutants; River Basin; River Watersheds

\section{Introduction}

A vital resource for all anthropogenic activity and landscape preservation is clean water availability. Back in history, humans have settled nearby water bodies, using them to satisfy their necessities as well as a waste disposal receptor; although in recent time, water carrying capacity has been overcome because of the rise in global population which increased the amount of wastes disposed onto rivers, lakes and lakeshores [1-7].

Worldwide the most common damage exerted onto surface waters has become evident through the eutrophication effect, since water bodies have become rich in phosphorus and nitrogen, nutrients whose origin can be either land farming activities or byproducts from wastewater organic matter degradation. These excessive nutrient concentrations exert negative impacts onto aquatic ecosystems. The most evident effect is proliferation of algae and macrophytes whose presence not only impacts water quality by degrading it, but also interferes with possible water use in recreation, industrial and agricultural activities, as well as reduces any possible applica-

\footnotetext{
${ }^{*}$ Corresponding authors.
}

tion to provide drinking water to the nearby communities [1-3]. It is worthy of mentioning that some decades ago eutrophication was considered a process taking place at lakes and ponds, but actually is having presence at rivers and lakeshores, a phenomenon that has been called "cultural eutrophication" $[3,5,6]$.

The target area of study The San Pedro-Mezquital river basin is a place mainly affected by agricultural runoff, municipal wastewater discharges, and solid waste disposal; additionally a vegetal coverage loss has increased. Authorities' efforts have not been successful because wastewater treatment plants have been operated in a wrong scheme of infrastructure and chemical treatment [4].

Since the San Pedro-Mezquital basin is the main source of water supply for the agricultural and urban zone of Durango City, this work presented an approach to determine the eutrophication levels along the basin, using as indicators key parameters for aquatic life such as soluble o reactive phosphorus $\left(\mathrm{PO}_{4}^{3-}\right)$, nitrogen as nitrates $\left(\mathrm{N}-\mathrm{NO}_{3}^{-}\right)$, and ammonium compounds $\left(\mathrm{N}^{-\mathrm{NH}_{3} /}\right.$ $\left.\mathrm{NH}_{4}^{+}\right)$, as well as dissolved oxygen percentage (\% DO). It is expected that the obtained results support recom- 
mendations that allowed implementation of actions for recovery and preservation according to the World Wildlife Foundation (WWF) principles.

\section{Materials and Methods}

\subsection{Description of the Target Place}

The study area belongs to the San Pedro-Mezquital basin. The river runs a pathway of about $540 \mathrm{Km}$, along it there are several name changes; it is born at the northwest of Durango City with the name of La Sauceda, afterwards and nearby the town of Nombre de Dios, the Tunal and the Santiago Bayacora branches join to La Sauceda, forming Durango River. Downstream it runs as Mezquital River crossing through the West Mountain Range flowing to Marismas Nacionales, at Nayarit State where it is designed as San Pedro-Mezquital River [4].

The basin comprises about 2.7 millions of hectares distributed over Durango, Nayarit and Zacatecas States. Onto this region, there are settled about 800,000 inhabitants whose main economic activities comprise livestock raising, forestry and farming; also, at the plains there are shrimp and oyster farms, activities which depends on having a healthy river [8].

In the San Pedro basin the yearly average runoff is about 1636 millions of cubic meters pouring over 25,990 $\mathrm{Km}^{2}$, from which 19,390 belong to Durango State.

Figure $\mathbf{1}$ is a map of Mexico, in which it is pointed the basin location in a red tone, and in Figure 2 it is shown an insight of the San Pedro river basin pathway, while in Figure 3 it is shown a close-up of the region where the location of sampling points are indicated.

\subsection{Sampling}

At the higher part of the basin 10 points for sampling were established; samples were collected under two conditions: 1) the rainy season of year (August) and 2) the dry season of the following year (March). In Table 1 are reported the local names for each sampling point.

Two samples of 1 and $3 \mathrm{~L}$ were collected at the middle of the river; in situ temperature (T) and dissolved oxygen (\%DO) were determined. Once measured, one $\mathrm{mL}$ of $\mathrm{H}_{2} \mathrm{SO}_{4}$ was added to the $1 \mathrm{~L}$ samples for fixing the ammonium to obtain the $\mathrm{N}-\mathrm{NH}_{3} / \mathrm{NH}_{4}^{+}$compounds. All samples were placed on ice and transported to the laboratory for further analyses.

In this study, eutrophication level determination is based on the presence of the following nutrients: nitrogen and reactive phosphorus, besides the \%OD for its relation with the eutrophication.

Ammonia compounds are present at the first stages of organic matter degradation, therefore in fresh domestic wastewater this is the main nitrogen form, in old waters the nitrate is the predominant specie. Then, nitrogen in

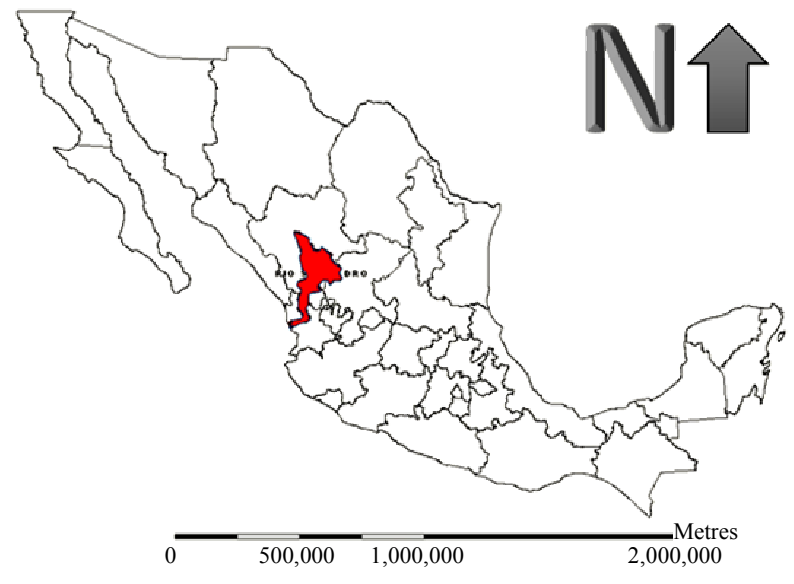

Figure 1. San Pedro River basin location.

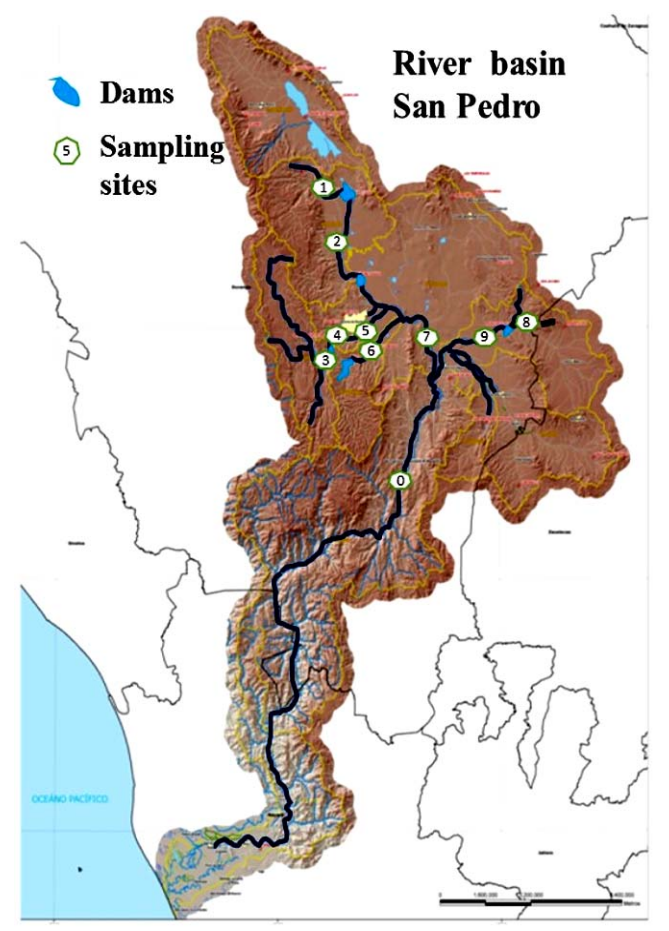

Figure 2. Insight of San Pedro River basin.

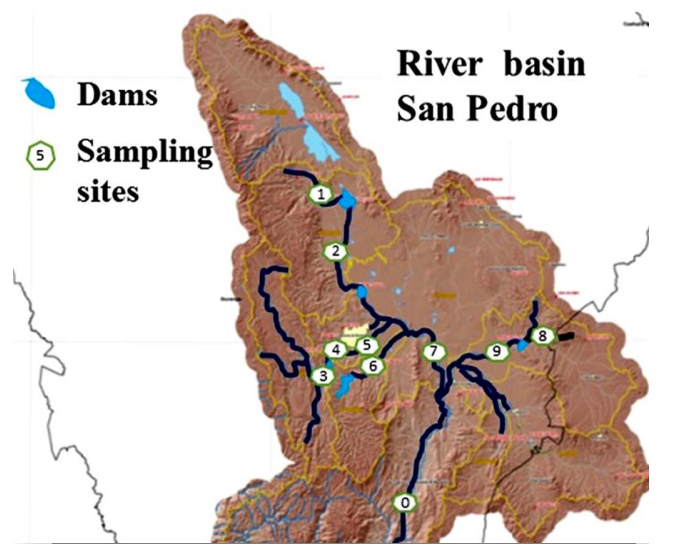

Figure 3. Sampling sites (1 - 10) along the river pathway. 
Table 1. Location of sampling points.

\begin{tabular}{cc}
\hline Point & Location \\
\hline 1 & Upstream Caboraca Dam \\
2 & Downstream Caboraca Dam \\
3 & Tres Molinos \\
4 & El Pueblito \\
5 & La Ferrería \\
6 & Refugio Salcido \\
7 & El Saltito \\
8 & Upstream Fco. Villa Dam \\
9 & Downstream Fco. Villa Dam \\
10 & Mezquital \\
\hline
\end{tabular}

either its nitrate form $\left(\mathrm{N}^{-\mathrm{NO}_{3}^{-}}\right)$or the ammonia form $\left(\mathrm{N}-\mathrm{NH}_{3} / \mathrm{NH}_{4}^{+}\right)$is a nutrient that allows for development and proliferation of primary producers; both forms were evaluated in a single determination, that is they were not separated by modifying the $\mathrm{pH}$ [9]. This parameter was analyzed by duplicate following the recommended procedure of Standard Methods for water and wastewater [10]. The amount of compound recovery is referred in respect to known concentration standards.

Reactive phosphorus is a limiting factor for aquatic vegetation development; it is known that its source belongs to detergent polyphosphates which are either directly discharged or they were not removed in the wastewater treatment plants. This parameter was determined by the Olsen method using a visible light spectrophotometer Spectronic 20 Genesys TM, calibrated with commercial standard solutions.

Dissolved oxygen parameter is used to qualitatively describe water quality; in natural environments oversaturation can be due to a high photosynthetic activity.

Otherwise, low oxygen concentrations can be an indicator of organic matter contamination as well as a high respiratory activity-taking place by natural processes. For this parameter measurement was done in situ at the river central path using a DO meter, model Orion 842 .

\subsection{Eutrophication Index Calculated for Each Nutrient}

The Karydis eutrophication index was calculated for each nutrient [11]. This index allows determination of the trophic state for each sampling site. The following considerations were applied in its formulation:

- It should be specific for each nutrient.

- It should account for the nutrimental contribution at any specific location.

- It should be dimensionless and used for several water types.

- It should be sensitive to eutrophication effects, simple in data handling and calculation.

The eutrophication index $(\boldsymbol{E I})$ is calculated with the following equation:

$$
\boldsymbol{E} \boldsymbol{I}=\frac{C}{C-\log X_{i}}+\log A
$$

In this equation $\boldsymbol{E I}=$ eutrophication index for each nutrient at each sampling point, during the study period; and it is composed by $\mathrm{M}$ samples.

$A=$ number of sampling points during the study period.

$X_{i}=$ total nutrient concentration at the $A_{i}$ sampling point during the study period; this data is the sum of nutrient concentrations obtained at the $A_{i}$ sampling point, during the $M_{j}$ sample collection.

$C=$ logarithm of total nutrient concentration during the study period; it is the sum of $X_{i j}$ nutrient concentrations obtained at the $A_{i}$ sampling point during the $M_{j}$ sample collection. This concentration is calculated with the following equation:

$$
C=\log \sum_{i=1}^{A} \sum_{j=1}^{M} X_{y}
$$

Obtained values of $\boldsymbol{E} \boldsymbol{I}$ can be match with the water trophic state as follows:

$\boldsymbol{E I}<3$ corresponds to an oligotrophic state;

$3 \leq \boldsymbol{E I} \leq 5$ corresponds to a mesotrophic state;

$5 \leq \boldsymbol{E I}$ corresponds to a eutrophic state.

\subsection{Statistical Analysis}

For validation of the differences in the analytical data it was used an ANOVA $10 \times 2$ factorial design with two replicates. Considered factors were: the sampling site (ten levels) and the season (two levels), also it was applied a Newman-Keuls media test, with a $\alpha=0.05$; analytical runs were executed with the Statistic v.7 software.

\section{Results and Discussion}

As it was mentioned before, water was sampled at two times: season I in August (rainy time), and season II in March (dry time).

\subsection{Analytical Results for Each Parameter}

3.1.1. Soluble or Reactive Phosphorus as $\mathrm{PO}_{4}^{3-}$ (RP) In natural surface waters, without eutrophication problems, the average concentration for RP should not exceed $0.01 \mathrm{mg} \cdot \mathrm{L}^{-1}$. The obtained analytical concentrations during the season I was as follow: 4 sites have RP below the $0.01 \mathrm{mg} \cdot \mathrm{L}^{-1}$, the others exhibit values between a minimum of $0.07 \mathrm{mg} \cdot \mathrm{L}^{-1}$ and a maximum of $2.4 \mathrm{mg} \cdot \mathrm{L}^{-1}$, with an average value of $0.73 \mathrm{mg} \cdot \mathrm{L}^{-1}$. During the season II, 
again 4 sites were under $0.01 \mathrm{mg} \cdot \mathrm{L}^{-1}$, while the others exhibit greater values with a maximum of $3.58 \mathrm{mg} \cdot \mathrm{L}^{-1}$, with an average of $0.52 \mathrm{mg} \cdot \mathrm{L}^{-1}$.

Applying the statistical analysis some significant differences were found between season I and season II, with an $F=5.05$ and a probability of 0.02768 , sites with greater variation in concentrations were El Mezquital, El Saltito, and downstream of Francisco Villa dam, the last two exhibit a raise in RP during season II, fact that can be attributed to a lower pollutant dilution since the river flow decreases; the other sites kept similar concentrations during both seasons.

\subsubsection{Dissolved Oxygen Saturation Percentage (\%DO)}

A good quality of water implies that $\% \mathrm{DO}$ should be between $80 \%-90 \%$, this means that there are not eutrophication symptoms. During season I a maximum concentration $(105 \%)$ was registered at the site upstream of the Caboraca dam, while the minimum (16\%) took place at Refugio Salcido. Otherwise during season II a maximum concentration (122\%) was registered at the upstream of the Fco Villa dam, while the minimum (68\%) happened at the site El Mezquital. The other sites exhibit values that can be accounted as normal.

Results of the statistical comparison between seasons indicate significant differences with $F=9.9421$ and a probability of 0.0023 , since oxygen concentrations exhibit a high variability between seasons.

Results of RP and \%DO are shown in Figure 4, sites whose average values were not statistically different are indicated with the same letter.

\subsubsection{Nitrogen as Ammonia Compounds} $\left(\mathbf{N}-\mathbf{N H}_{3} / \mathbf{N H}_{4}^{+}\right)$

Ammonia content in healthy waters should be between 0.007 and $0.02 \mathrm{mg} \cdot \mathrm{L}^{-1}$. The concentrations detected in season I exhibit a minimum of $0.01 \mathrm{mg} \cdot \mathrm{L}^{-1}$, a maximum of $6.52 \mathrm{mg} \cdot \mathrm{L}^{-1}$ and an average of $2.76 \mathrm{mg} \cdot \mathrm{L}^{-1}$, sites with higher concentrations were La Ferreria, El Pueblito and El Saltito; at the Fco Villa dam there was not ammonia concentration at both sites upstream and downstream.

During season II values were higher than the ones observed during season $\mathrm{I}$ since the minimum was 0.0 $\mathrm{mg} \cdot \mathrm{L}^{-1}$, the maximum was $20.73 \mathrm{mg} \cdot \mathrm{L}^{-1}$, with an average of $3.72 \mathrm{mg} \cdot \mathrm{L}^{-1}$; in this season sites with ammonia presence were La Sauceda, El Saltito, El Mezquital and Refugio Salcido.

Statistical analysis results indicate that there are few differences in the obtained ammonia concentrations; also between seasons were detected few differences, since $F=$ 3.5842 with a probability of 0.0624 .

For this parameter the only significant difference corresponds to El Saltito where ammonia exhibited an im-
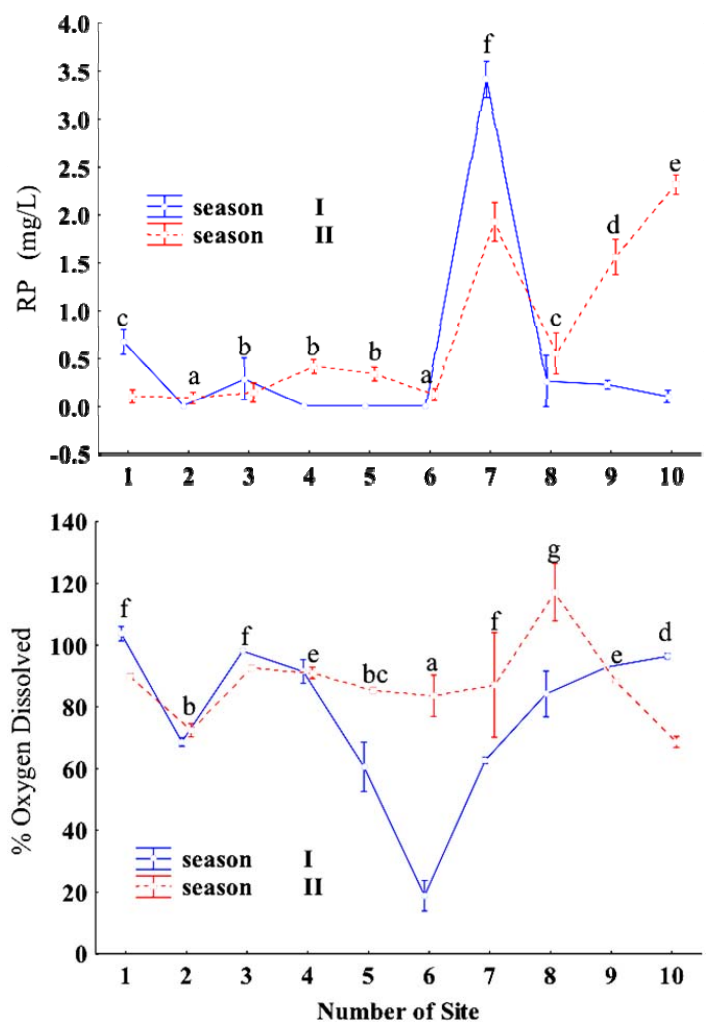

Figure 4. RP and \%DO statistical differences.

portant concentration raise during season II.

3.1.4. Nitrogen as Nitrate Compounds $\left(\mathrm{N}-\mathrm{NO}_{3}^{-}\right)$ Nitrate concentration at waters without eutrophication should be lower than $1 \mathrm{mg} \cdot \mathrm{L}^{-1}$. During season I concentration values exhibited a minimum of $0.01 \mathrm{mg} \cdot \mathrm{L}^{-1}$, a maximum of $1.15 \mathrm{mg} \cdot \mathrm{L}^{-1}$, and an average concentration of $0.36 \mathrm{mg} \cdot \mathrm{L}^{-1}$, fact which in general allow affirm that most sites exhibit normal values during rainy time. The opposite occurs at season II since the minimum detected was $0.01 \mathrm{mg} \cdot \mathrm{L}^{-1}$; the maximum was $526 \mathrm{mg} \cdot \mathrm{L}^{-1}$ with an average of $53.32 \mathrm{mg} \cdot \mathrm{L}^{-1}$.

Statistical analysis show that there are significant differences between sites or between seasons since $F=$ 9.2138 with a probability of 0.0033 .

For this parameter the only site which makes a difference was found at the Fco Villa dam, in the downstream position where there is a high nitrate concentration, it is thought that this raise in concentration is due to fertilizer presence in both infiltration and run off, since this site is surrounded by agricultural farms.

Results for ammonia and nitrate are shown in Figure 5, sites with similar concentrations are indicated with the same letter.

\subsection{Eutrophication Index (EI)}

Results for the season I are presented in Table 2. 
Table 2. Eutrophication index for Season I.

\begin{tabular}{cccc}
\hline Number site & $\mathrm{PO}_{4}^{3-}$ & $\mathrm{N}^{3-} \mathrm{N}_{3} / \mathrm{NH}_{4}^{+}$ & $\mathrm{N}-\mathrm{NO}_{3}^{+}$ \\
\hline 1 & 2.5 & 2.6 & 1.4 \\
2 & 1.5 & 2.4 & 1.7 \\
3 & 2.1 & 3.1 & 1.4 \\
4 & 1.5 & 3.7 & 1.4 \\
5 & 1.5 & 4.3 & 1.4 \\
6 & 1.5 & 3.2 & 1.6 \\
7 & 9.2 & 3.6 & 3.4 \\
9 & 2.0 & 1.6 & 2.9 \\
10 & 1.8 & 1.5 & 2.0 \\
\hline
\end{tabular}

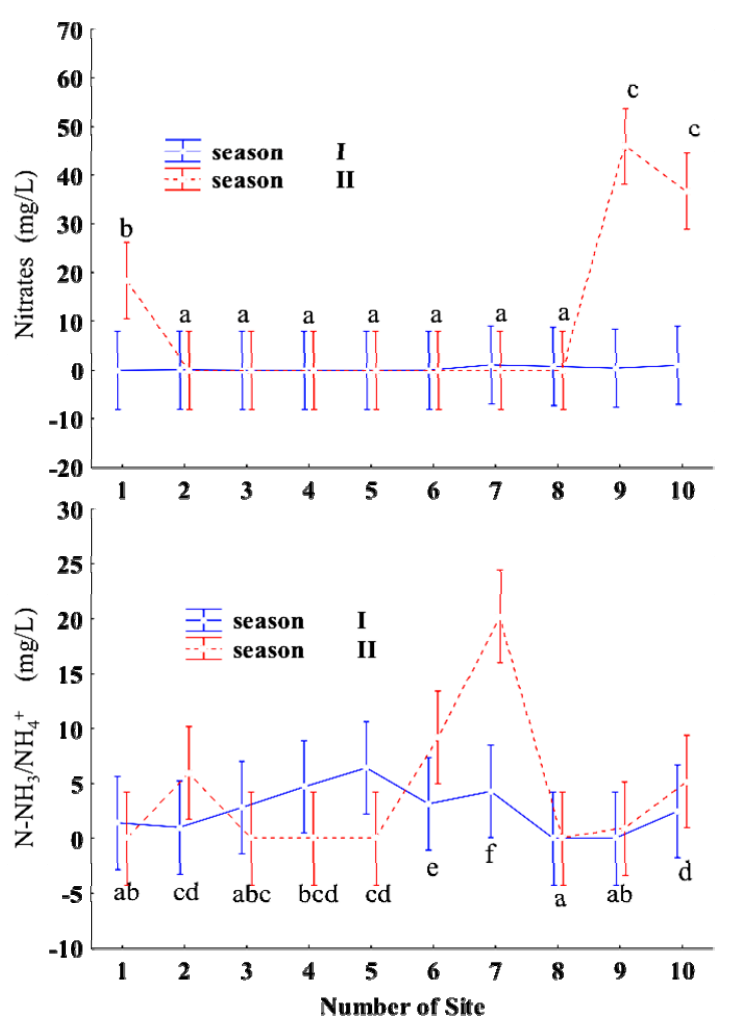

Figure 5. Nitrogen statistical differences.

Classification is done taking into consideration the intervals mentioned paragraphs above. As can be observed there are 3 sites that can be classified as oligotrophic (green) because the $\boldsymbol{E I}$ index for the three parameters fall in this category. Based on the ammonia presence 6 sites can be classified as mesotrophic (yellow); in reference to the RP only one site is classified as eutrophic (red); finally considering the nitrate parameter only 3 sites can be classified as mesotrophic (yellow).

It is worthy to point out that site 7 (El Saltito) is the most deteriorated in RP and ammonia; this fact agrees with the environment surrounding the site, since this place is receiving wastewater from a paper industry and from Durango city which accounts for 600,000 habitants. Also, river path runs across agriculture lands, and applied fertilizer can increase the nitrate content arriving to the site.

Another site of concern is El Mezquital (site 10) which is classified as mesotrophic for nitrogen compounds, a logical fact since it is receptor of municipal wastewater from it, which is a city having 80,000 habitants.

Results from season II are presented in Table 3. As it can be observed based on the three nutrients only 3 sites can be considered oligotrophic (green); considering the RP three sites can be classified as mesotrophic (yellow), and the other 7 correspond to an oligotrophic category (green); in reference of ammonia 6 sites are oligotrophic (green), 3 mesotrophic (yellow) and 1 eutrophic (red); but considering nitrate presence 3 sites are classified as mesotrophic (yellow), 6 are oligotrophic (green) and there is one eutrophic site (red) which exhibits the higher $\boldsymbol{E I}$ value, but this site is located in an agriculture zone. In general sites 7 and 10 are the ones with greater eutrophication because they are receptors of municipal wastewater.

\section{Conclusions}

Diagnosis of the trophic state for rivers is a task that will provide a panorama of the pollution problems that are evolving in them, once the affectation level has been diagnosed it is possible to set up recommendations to control pollution.

From obtained results of nutrient concentrations from 10 sites and 2 seasons, applying a statistical analysis and calculation of the Eutrophic Index, it was possible to elaborate the diagnosis for the trophic state of the San

Table 3. Eutrophication index for season II.

\begin{tabular}{|c|c|c|c|}
\hline Number site & $\mathrm{PO}_{4}^{3-}$ & $\mathrm{N}-\mathrm{NH}_{3} / \mathrm{NH}_{4}^{+}$ & $\mathrm{N}-\mathrm{NO}_{3}^{+}$ \\
\hline 1 & 1.8 & 1.8 & 3.3 \\
\hline 2 & 1.8 & 3.8 & 1.9 \\
\hline 3 & 1.9 & 1.8 & 1.9 \\
\hline 4 & 2.2 & 1.8 & 1.9 \\
\hline 5 & 2.1 & 1.8 & 1.9 \\
\hline 6 & 1.8 & 4.6 & 1.9 \\
\hline 7 & 3.1 & 6.7 & 1.9 \\
\hline 8 & 2.3 & 2.0 & 3.3 \\
\hline 9 & 3.2 & 2.3 & 70.5 \\
\hline 10 & 4.0 & 3.6 & 3.3 \\
\hline
\end{tabular}


Pedro-Mezquital basin, which can be classified as oligotrophic in most of the sampled sites.

It is possible to establish that there is a significant difference between seasons, being the dry one (season II), which accounts for the higher nutrient content. Specifically the ammonia content $\left(\mathrm{N}-\mathrm{NH}_{3} / \mathrm{NH}_{4}^{+}\right)$was high for both seasons.

Also, sites with major damage can be considered those nearby to places with high population.

The site with high nitrate concentration should be carefully observed to find if this concentration belongs to fertilizer procedures or if this concentration comes from ammonia conversion.

\section{Acknowledgements}

We thanks to World Wildlife Foundation for the economic support to do this work.

\section{REFERENCES}

[1] A. McQuatters-Gollop, A. J. Gilbert, L. D. Mee, J. E. Vermaat, Y. Artioli, C. Humborg and F. Wulff, "How Well Do Ecosystem Indicators Communicate the Effects of Anthropogenic Eutrophication," Estuarine, Coastal and Shelf Science, Vol. 82, No. 4, 2009, pp. 583-596. http://dx.doi.org/10.1016/j.ecss.2009.02.017

[2] L. W. Canter, "Environmental Impact Assessment," 2nd Edition, McGraw-Hill, 1998.

[3] D. Chapman, "Water Quality Assessment," 1st Edition, Chapman and Hall, London, 1992. http://dx.doi.org/10.4324/9780203476710

[4] National Water Commission (NWC), "The polluted Tunal
River: San Pedro Basin Restoration Project," 1st Edition, CNA, 2005.

[5] S. Bonilla, "Planktonic Cyanobacteria from Uruguay, Identification and Management Manual," 1st Edition, Regional Office for Science of UNESCO for Latin-American and the Caribbean, Uruguay, Montevideo, 2009. http://unesdoc.unesco.org/images/0021/002163/216319s. pdf

[6] X. Yang, X. Wu, H. L. Hao and Z. L. He, "Mechanisms and assessment of water eutrophication," Journal of Zhejiang University SCIENCE A, Vol. 9, No. 3, 2008, pp. 197-209. http://dx.doi.org/10.1631/jzus.B0710626

[7] V. H. Smith, G. D. Tilman and J. C. Nekola, "Eutrophication: Impacts of Excess Nutrient Inputs on Freshwater, Marine, and Terrestrial Ecosystems," Environmental Pollution, Vol. 100, No. 1-3, 1999, pp. 179-196. http://dx.doi.org/10.1016/S0269-7491(99)00091-3

[8] WWF, "Integrated Management of the San Pedro-Mezquital River Basin," 2008.

http://awsassets.panda.org/downloads/cuenca_alta_del_ri o_spm_2010_1.pdf

[9] S. L. Miliarium Aureum, “Aquifer Vulnerability,” 2008. http://www.miliarium.com/Monografias/Nitratos/Vulnera bilidad.asp

[10] APHA American Public Health Association, "Standard Methods for the Examination of Water and Wastewater Analysis," 19th Edition, AWWA-WEF, Washington D.C., 1995.

[11] C. N. Aranda, "Eutrophication and Water Quality in a Tropical Costal Zone," Ph.D. Doctoral Thesis, University of Barcelona, Barcelona, 2004. http://www.tesisenxarxa.net/Tesis_UB/.../TDX...//TESIS NANCY.pdf 